\title{
Globalization, Democracy and Child Health: Asia vs. Latin America
}

\author{
Hijab Agha ${ }^{1}$, Faiza Azhar Khan ${ }^{2}$ and Sadia Sherbaz ${ }^{3}$
}

\begin{abstract}
Child mortality in an important indicator of shortcomings in health provisions to the most vulnerable segments of the society i.e., children under five. In this highly connected world, the trends in child mortality need exploration within the context of institutional change and global connectivity. This study explores the effect of globalization on child health in Asia and Latin America. These two regions over the last three decades have undergone waves of liberalization as well as an inconsistent drive towards democratization with very different outcomes in terms of child mortality, making for apt comparison in the context of this study. The study also examines how the level of democracy changes the relationship between globalization and child health in the two regions for the time-period 1970 to 2016 using System GMM estimation technique. The results indicate that economic globalization improves child health in Asia while social and political globalization show different results for infant and child mortality. In Latin America political globalization was found to be most effective in reducing infant mortality, while all dimensions of globalization were found to be either insignificant or increasing under-five mortality. That said, the interactions between dimensions of globalization and democracy were found to be consistently significant and mortality reducing. This result signifies the existence of complementarity between democracy and globalization in improving child health outcomes.
\end{abstract}

Keywords: Globalization, Democracy, Under-Five Mortality, Infant Mortality, Dynamic Panel System GMM

JEL Codes: F63

\section{Introduction}

Globalization has changed the world in a number of significant ways. It has expanded the horizons of our knowledge and gave us access to technologies from across the planet. It has also made transfer of information more feasible, including basic rules of hygiene and lifesaving medicinal knowledge etc. At the same time, globalization has made transfer of diseases more convenient, resulted in

\footnotetext{
${ }^{1}$ M.Phil Graduate, Department of Economics, Fatima Jinnah Women University (FJWU), The Mall, Rawalpindi, Pakistan. ${ }^{2}$ Assistant Professor, Department of Economics, Fatima Jinnah Women University (FJWU), The Mall, Rawalpindi, Pakistan. ${ }^{3}$ Lecturer, Department of Economics, Fatima Jinnah Women University (FJWU), The Mall, Rawalpindi, Pakistan. Corresponding author's Email: faiza.fjwu@gmail.com
} 
environmental degradation and enhanced access to potentially dangerous products and their influences (Woodward et. al, 2001).

The effect of globalization on life chances of the young is ambiguous at best. On one hand, is Sinn (1997) race-to-the-bottom scenario, by curtailing government's ability to finance necessary healthcare due to reduction in tax revenues owing to globalization. Supported by Rudra (2002) implying that globalization has led to decline in welfare state in developing nations. Globalization can also lead to a brain drain where educated and highly skilled workers migrate to find job where wages are higher. Historically doctors and nurses have displayed a high international mobility (Mills, 2011). Furthermore, globalization may have negative effects on the health of children in low-income countries through faster spreading of infectious diseases (Papageorgiou et al., 2007; Deaton, 2004).

On the other hand, there is compensation hypothesis given by Rodrik (1998) which posits that in the presence of health risk, owing to openness, a democratic government has to step-up. This results in an increase in the size of the government and provision of public health services. This work signifies that globalization can improve life chances of the young if accompanied by higher democratic accountability. This gives an idea that a functioning democracy can control and manage the effects of globalization by inducing governments to compensate the masses for risk and uncertainty. This might include investing in provision of healthcare or putting in place other welfare enhancing schemes to cover for the risk of reduction in income or loss of employment (Besley and Kudamatsu, 2006; Rudra and Haggard, 2005).

This issue is relevant to the world as a whole but the potential of democracy in rendering globalization beneficial for the masses in terms of extracting positive health outcomes is especially poignant in case of Latin American and Asia. These two regions have made notable strides in economic development over the past couple of decades. Both regions embarked on a policy of greater openness and integration with the rest of the world in the 1980s (Kohli, 2012). However, as far as child health status goes, the two regions follow very different trajectories. Immediately after the end of Cold War, Latin American and Caribbean nations faced median under-five mortality of about 0.646 million and infant mortality of about 0.513 million. Over the past 25 years these figures have been brought down 0.188 million and 0.159 million respectively. In contrast post-Cold War Asian nations experienced a median under five mortalities of about 7.5 million and infant mortality of 5.5 million, which has been reduced to 2.1 million and around 1.7 million, respectively in 2017 (UNICEF, 2018). 
Figure A-1 in Appendix shows that infant mortality has seen a declining trend from the years 1970-2017, for both the region viz. Asia and Latin America. However, this falling trend took a pace earlier in Latin America and Asia later sped its improvement rate as well. For instance, in 1970, when Asia's infant mortality was still $92.8 \%$, Latin America was already at $84.2 \%$. This gap widened in year 1980, when Asia's infant mortality rate fell to 67.8\%, while Latin America's had already fallen to $58.7 \%$. Like mentioned earlier, Asia picked up some speed in improving the infant mortality rate and so in the year 2000 its rate fell to $32.4 \%$, almost catching up to Latin America then rate of $27.3 \%$. This difference became even thinner in 2015 when Asia's mortality rate dropped to $18.2 \%$ while Latin America's to $16.8 \%$.

Interestingly, Latin American countries are considered to be a lot more democratic than Asian countries. This may be because of the reason that democratization came to Asia much later than Latin America. Right after the WWII (1939-1945), Japan was the only stable democracy in the whole of the Asian region. Although Philippines, Thailand and Vietnam too had democratic system, they frequently interrupted by military or communist coups. Contrastingly, many of the Latin American countries were declared democracies even at the time of independence (1776). Therefore, in the postwar era, as well, many countries like Costa Rica, Venezuela and Colombia had stable democracies. This situation changed drastically after 1960s, when a number of democracies in both the regions, more so in Latin America, were deposed at the hands of military coups and bureaucratic-authoritarian regimes. However, since the end of Cold War most Latin American countries are governed by democratically elected governments. In Asian countries, especially the Middle East and Central Asia, certain autocratic governments persevere to date (Fukuyama and Marwah, 2000). ${ }^{4}$ The democracies where they do exist are dynastical and level of accountability remains on average low.

This brings us to the puzzle and the main motivation of study for exploring whether this severe discrepancy in infant and child mortality between Latin America and Asia, despite opening up around the same time-period, is a result of differential progress in democratic reforms in the two regions. Further, the study

\footnotetext{
${ }^{4}$ The International Country Risk Guide marks Latin American countries better than Asian countries, owing to the level of corruption, while Asian countries better than Latin American countries, if rule of law and bureaucracy indicator is considered. Similarly, 1999 Transparency International Corruption Perception Index reports Latin America to be less corrupt if overall averages of countries are taken, while averages by population show that Asia is more corrupt (mostly due to China). Variance in corruption levels is higher in Asia; where, Singapore is considered a very honest nation, China and Indonesia are extremely corrupt.
} 
also aims to compare the effectiveness of democracy in altering the link between globalization and infant and child mortality. While this aspect of the relationship between globalization and child health has been explored, particularly by Welander et al. (2015) that analysis did not factor in the regional differences within the selected developing nations. We hypothesize that:

- Globalization has detrimental effects on child health in Latin America and Asia

- Democracy neutralizes the detrimental effect of globalization on child health in both the regions

The confirmation of both the hypotheses will establish and explain the role of democracy in enabling Latin American countries to capitalize on the opportunities presented by globalization while avoiding its negative implications vis a vis child health status. At the same time, it would also explain the reason for Asian countries failing to improve the lot of its young adequately.

The study is based on a data from 31 Asian and 22 Latin American nations for the time- period 1970 to 2018. In order to explore the targeted relationships, dynamic panel system GMM estimation technique is applied for both the regions separately. This has made possible meaningful regional comparison and draw policy recommendations catering towards particular regional needs.

The paper proceeds with brief literature review in Section 2. While Section 3 deals with model specification and data analysis. The discussion of estimated results is presented in Section 4. Finally, the study is concluded in Section 5.

\section{Literature Review}

To have an idea about a country's child health situation, different researchers use different indicators like infant mortality rate, under-five mortality rate, malnutrition indicators, etc. Developed countries generally have better child health indicators than the developing world. This is mostly because of lack of resources and misplaced focus (Rosenfield and Schwartz, 2005; Kickbusch, 2004; Östlin, 2004). Globalization may play a notable role in determining many factors that shape the household utility function, one such important variable is child health (Welander et al., 2015). Also, globalization influences the policies of a country which includes provision of healthcare (Wamala, 2009). The impact of globalization on child health outcomes is largely shaped by the nature of political regime in a country (Welander et al., 2015). 
Researchers argue that it is not only the prevalence of a democratic system in a country that helps improve its health status, but the age, strength and efficiency of that system matters too. Weak democracies are usually unable to sustain any external pressure and can even allow Multinational Corporations to exploit national resource base, leaving little if any for greater public concerns like healthcare. Similarly, an inefficient democracy, lacking drive to meet social goals and provision of basic needs, also slows down the progress in way of healthcare provision (Keefer, 2007; Shandra et al., 2005; Spalding, 1990). Conversely, healthier democracies, that promote family planning and target other improvements, appear to have a healthier population (Seyfried and Bednarzik, 2011; Besley and Kudamatsu, 2006).

The impact of globalization on health is much debated on. While, some researchers are of the view that globalization promotes health-deteriorating lifestyles and stresses, pushes up under-five mortality rates and other social indicators (Azevedo and Johnson, 2011; Tanahashi (2007); Zgurovsky, 2007). Others argue that globalization tends to improve the child health situations in most countries (Martens et al., 2010), and that openness tends to decrease infant mortality, child mortality and stunting (Levine and Rothman, 2006). There are also some studies that posit that globalization can have both, a negative as well as a positive impact on child health. The negative impact is mostly on account of transfer of diseases and reduction in government's ability to provide effective healthcare to all. The positive effect mostly manifests by enhancing access to information about prevention and treatment of diseases, life-saving medicines and supplements, and technology (Bhalotra and Pogge, 2012; Deaton, 2004; Olayiwola et al., 2004; Diaz-Bonilla et al., 2002; Cornia, 2001).

Not many work has been conducted on the nexus of child health, globalization and democracy. Using multilevel modeling, Burroway (2016) found that while economic development measured by GDP per capita and improved sanitation have positive effect on child health; the impact of democracy was found to be negative albeit insignificant. The author posits that despite democratization, developing countries are influenced by outside agendas, which keep them from asserting their own policy priorities.

Welander et al. (2015) use panel data co-integration technique and reported that globalization accompanied by more democratic institutional arrangement improves child health. The quality of democracy has an impact on the intensity of globalization and its relationship with child health. This result reinforces the findings of Bergh and Nilsson (2010) who highlight the positive impact of political 
institutions on globalization-on-health effect by reporting that in common-law countries, globalization boosts health, while in civil law countries, evidence of such an association cannot be found. This also gives credence to the idea that political institutions need to be flexible and open-to-interpretation with changing realities. Democracy enables a common-law based formal institutional framework to reflect greater concerns of the masses, reflected in better health outcomes along with other indicators of wellbeing. Rudra and Haggard (2005) reported that under democratic regimes, social welfare spending is regulated and maintained thus is relatively less sensitive to globalization, compared with an authoritarian system. Therefore, globalization and democracy together can help to increase social welfare spending, which includes spending on health, education, and social security. This trait makes open high-quality democracies potentially effective in decreasing negative health outcomes for children and infants.

Child health and globalization are related with each other. Although there is little evidence on this issue, it makes intuitive sense that globalization has significant implications for child health and life chances. Available literature clearly shows that this effect is shaped by the political system prevalent in the country. However, literature does not carry out regional comparisons on the issue. We have already discussed in the last section that regional comparisons can shed a much brighter light on the matter and can potentially allow us to draw useful policy conclusion pertinent to a specific region.

\section{Methodology and Data}

To begin with, the model of health utility given by Torrance et al. (1972), is considered such that:

health utility $=f$ (endogenous factors, exogenous factors)

Where, endogenous factors are the health and financial endowments one is born with, while the exogenous factors are the variety of external costs and challenges one's health faces. Proceeding with the typical model of child health production given by Currie (2009) in which parents of the children usually maximize an inter-temporal utility function of the form:

$\sum_{t=1}^{T} E_{t}\left(\frac{1}{(1+\sigma)^{t}}\right) U_{t}+\beta\left(A_{T+1}\right)$

where the discount rate is denoted by ' $\sigma$ ', $\beta$ is a bequest function, assets are denoted by 'A', and ' $U$ 't is given by:

$U_{t}=f\left(Q_{t}, C_{t}, L_{t} ; X_{t}, \mu_{1}, \varepsilon_{1 t}\right)$ 
In equation (3), stock of child health is represented by ' $Q$ ', while consumption of other goods is denoted by ' $\mathrm{C}$ ' and ' $\mathrm{L}$ ' is leisure, $\mathrm{X}$ is a vector of exogenous variables, $\mathrm{u}$ is an error term, and $\varepsilon$ denotes a shock to preferences. Utility maximization is constrained to material and time inputs into health production. Further, production function for child health under this utility maximization problem is given by:

$Q_{t}=f\left(Q_{t-1}, G_{t}, V_{t} ; Z_{t}, \mu_{2}, \varepsilon_{2 t}\right)$

Here, $G_{t}$ represents material inputs and $V_{t}$ represents time inputs into this health production function. $Z_{t}$ is a vector of exogenous variables, $\mathrm{u}_{2}$ is an error term, and $\varepsilon_{2}$ denotes a productivity shock.

A similar type of utility model has been contended by Welander et al. (2015), such that:

household utility=

$f$ (parentalhealth, childhealth, consumption of household good sincluding

leisure and exogenous taste factors)

Also, that,

childhealth $=$

$f$ (material and time inputs, parental education, environmental factors)

Adapting elements from the models specified above along with models of different studies on determinants of child health such as Wang (2003), Mutunga (2011), Zakria et al. (2020), following specific form of model has been used for estimations:

$\mathrm{CH}_{i_{t}}=\alpha+\beta_{1} \mathrm{CH}_{i t-1}+\beta_{2}$ Glob $_{i t-1}+\beta_{3}$ Dem $_{i t-1}+\beta_{4}$ Glob $_{i t-1} \times$ Dem $_{i t-1}+$ $\beta_{5} A F R_{i t}+\beta_{6} P C I G_{i t}+\beta_{7} L F P F_{i t}+\beta_{8} H E_{i t}+\beta_{9} T R_{i t}+\beta_{10} I N F_{i t}+\beta_{11} A H_{i t}+$ $\beta_{12} H K_{i t}+\varepsilon_{i t}$

Where, $\mathrm{CH}_{i t}$ presents child health (infant mortality and under-five mortality), Glob ${ }_{i t-1}$ is the first lag of globalization, $\operatorname{Dem}_{i t-1}$ is the first lag of democracy and Glob $_{i t-1} \times$ Dem $_{i t-1}$ is the interaction term of lagged globalization and lagged democracy. Control variables include $\mathrm{AFR}_{i t}$ for adolescent fertility rate, $\mathrm{PCIG}_{i t}$ as real GDP per capita growth, $\mathrm{LFPF}_{i t}$ presents female labor force participation rate, $\mathrm{HE}_{i t}$ as health expenditure, $\mathrm{TR}_{i t}$ denotes tax revenues, $\mathrm{INF}_{i t}$ for inflation rate, $\mathrm{AH}_{i t}$ presents adult health (life expectancy) and $\mathrm{HK}_{i t}$ stands for human capital. 
For cross-country macroeconomic analyses, infant mortality rates and under-five mortality rates capture the health outcomes for children particularly in developing countries. While in developed countries major health problems of children are associated with lifestyle choices e.g., issue of obesity and allergies. In developing countries, major health issues faced by infants and children under five are potentially life threatening i.e., premature births, congenital disorders, birth trauma and diarrhea. All these issues are not only life threatening but also, tragically, preventable, this makes infant mortality rate and under five mortality rate fitting indicators for analyzing child health status in developing nations. Different studies have used infant and child mortality rates as indicators of child health such as Dithmer and Abdulai (2020), Wagner, et al. (2018) and Welander et al. (2015).

The study incorporates the lagged values of democracy and globalization following Welander et al. (2015), as they are of the view that neither their separate effect on child health is instant, nor their interaction term's. They also posit that use of lagged values reduces the risk of reverse or two-way causality and measurement errors. The variable of globalization has been incorporated in three dimensions namely, economic, social and political globalization. The impact of each dimension is then assessed independently and through its interaction with democracy, in line with the objectives of the paper. Equation (7) is first estimated for the two separate child health indicators, namely, infant mortality and under-five mortality, and then also estimated separately for each dimension of globalization, for the two regions under study. This is because, taking the three dimensions together in a model causes the problem of multicollinearity (Dreher, 2006).

Measurement of variables is based on the studies of Azevedo and Johnson (2011), Tanahashi (2007), Zgurovsky (2007), Martens et al. (2010) and Levine and Rothman (2006). Globalization has been measured through KOF index. The overall globalization variable is composed of economic, social and political globalization. Where, economic globalization encompasses actual flows, which are an amalgam of trade, FDI, portfolio investment and income payments to foreign national, and restrictions, which encapsulate hidden import barriers, mean tariff rate, taxes on international trade and capital account restrictions. Social globalization includes data on personal contact, which includes telephone traffic, international tourism, transfers as a percentage of GDP, international letters per capita and foreign population as a percentage of total population, information flows, which includes internet users per 1000, trade in newspapers as a percentage of GDP and ownership of a television set per 100 people, and cultural proximity, which encapsulates number of McDonald's restaurants per capita, trade in books as a percentage of 
GDP and number of Ikea stores per capita. While political globalization is measured by consulting data on the in-country embassies in a country in terms of absolute number, number of country's memberships in international organizations in absolute terms, absolute number of UN security council missions a country has participated in and the number of international treaties signed by a country (Dreher, 2006 and 2008).

Democracy in the model has been represented by the polity 2 measure introduced through the Polity IV Project. Such a measure for democracy has also been used by Welander et al. (2015). Furthermore, adult health is proxied through life expectancy and has also been made use of by Currie (2008) data on life expectancy variable is accessed from World Development Index. The data for human capital index has been acquired from Penn World Table, version 9.0. It is based on returns to education and years of schooling. Data on adolescent fertility rate, inflation rate, annual GDP per capita growth rate, female labor force participation, health expenditures and tax revenue are also accessed from WDI.

This data has been collected and organized for thirty-one Asian and twentytwo Latin-American countries over the time-period 1970-2018. Furthermore, inclusion of lagged dependent as independent variable necessitates the use of a dynamic panel investigation. Dynamic panel estimation is also used because panel data has a tendency to have general or panel-specific autocorrelation. Finally, existence of endogenous regressors in the model also requires dynamic panel estimation technique. Two alternative options for estimating dynamic panel data is the first differenced and system GMM estimation techniques. However, contemplating on the dynamic panel data estimators, Hayakawa (2007) concluded system GMM estimation technique to be least biased compared to that of the first differenced GMM.

\section{Results and Discussions}

Results for Equation (1) for the whole sample are presented in Table 1. System GMM estimation technique through xtabond 2 command has been applied and there is no second order autocorrelation present in any of the two equations. Results show that the lag of the dependent variable, Infant Mortality (IM), has a positive and significant effect. Also, that the results are robust and the over identification restrictions are satisfied. 
Table 1: Globalization, Democracy and Child Health: Full Sample Results

\begin{tabular}{|c|c|c|}
\hline Variable & Infant Mortality & Under-five Mortality \\
\hline Intercept & $\begin{array}{c}1.124 \\
(0.890)\end{array}$ & $\begin{array}{c}-3.664 \\
(0.685)\end{array}$ \\
\hline $\mathbf{I M}_{\mathrm{it}-1} / \mathbf{U M}_{\mathrm{it}-1}$ & $\begin{array}{l}0.986^{* * * *} \\
(0.000)\end{array}$ & $\begin{array}{l}0.987 * * * \\
(0.000)\end{array}$ \\
\hline Glob $_{\text {it-1 }}$ & $\begin{array}{c}0.060 * * * \\
(0.007)\end{array}$ & $\begin{array}{l}0.065^{* *} \\
(0.010)\end{array}$ \\
\hline Dem $_{\text {it-1 }}$ & $\begin{array}{c}0.177 * * * \\
(0.009)\end{array}$ & $\begin{array}{l}0.170 * * \\
(0.030)\end{array}$ \\
\hline Glob $_{\text {it-1 }} *$ Dem $_{\text {it-1 }}$ & $\begin{array}{l}-0.002 * \\
(0.071)\end{array}$ & $\begin{array}{l}-0.002 * \\
(0.091)\end{array}$ \\
\hline $\mathbf{A F R}_{\text {it }}$ & $\begin{array}{l}-0.005 \\
(0.500)\end{array}$ & $\begin{array}{l}-0.002 \\
(0.821)\end{array}$ \\
\hline $\mathbf{I N F}_{\text {it }}$ & - & $\begin{array}{c}0.00006 \\
(0.813)\end{array}$ \\
\hline PCIG $_{\text {it }}$ & $\begin{array}{l}-0.026^{*} \\
(0.095)\end{array}$ & $\begin{array}{l}-0.029^{*} \\
(0.086)\end{array}$ \\
\hline $\mathbf{L F P F}_{\text {it }}$ & $\begin{array}{l}-0.010 \\
(0.462)\end{array}$ & $\begin{array}{l}-0.019 \\
(0.257)\end{array}$ \\
\hline $\mathbf{T R}_{\mathrm{it}}$ & - & $\begin{array}{l}-0.015 \\
(0.303)\end{array}$ \\
\hline $\mathbf{A} \mathbf{H}_{\mathrm{it}}$ & $\begin{array}{l}-0.044 \\
(0.699)\end{array}$ & $\begin{array}{c}0.014 \\
(0.914)\end{array}$ \\
\hline $\mathbf{H K}_{\text {it }}$ & $\begin{array}{l}-0.456 \\
(0.321)\end{array}$ & $\begin{array}{l}-0.232 \\
(0.697)\end{array}$ \\
\hline $\begin{array}{l}\text { No. of observations/ No. } \\
\text { of countries }\end{array}$ & $1984 / 49$ & $1831 / 46$ \\
\hline $\mathbf{A R}(2)$ & 0.269 & 0.118 \\
\hline Hansen test ( $p$ value) & 1.000 & 1.000 \\
\hline
\end{tabular}

Note: P-values of each coefficient are reported in (). ***, ** and * show 1\%, 5\% and $10 \%$ level of significance, respectively. Results for AR (2) and p-value for Hansen test are also mentioned. Results are estimated using GMM technique.

Beginning with the focused variable of the model, Globalization has a positive and significant impact on infant mortality rate, as well as under-five mortality rate. According to Sinn (1997), an increase in the level of globalization can be through reduced taxes and declining government social spending, lead to a race-to-the-bottom atmosphere and thus prove to be harmful for child health. This outcome is also supported by Mills (2011), who posits that globalization affects child health negatively, as doctors and nurses may migrate out of a low-wage country, thus brain drain can increase infant mortality. Tanahashi (2007) blames the social and economic disparities caused by globalization for this negative effect.

Democracy is positively and significantly related with infant mortality and under-five mortality rate. This result is counter-intuitive since democracy according to our expectations is to be negatively linked with child and infant mortality. This lends credence to the idea of quality of democracy, and its effectiveness in providing public services. Democracies in theory are to be accountable to masses and the indicator shows higher values for parliamentary democracies. 
Unfortunately, in developing countries, especially in new democracies parliament comprises almost exclusively of elites. While constitution restricts the authority of the executive, it also restricts the ability of the executive in carrying out accountability of elected representatives. Lack of education and ignorance regarding basic rights skews the priorities of the masses and may result in them not prioritizing health. This might account for the positive and significant effect of democracy on child and infant mortality rates

The positive effects of globalization diminish in the presence of democracy as it is apparent from the negative sign and significance of the interaction term. This indicates that democracy helps reducing the adverse effect of globalization on child health. The comparison of the coefficients of globalization and the interaction term, further explains that in presence of democracy, globalization improves child heath through reducing infant and under-five mortality rates. This effect is in-line with the effect estimated by Welander et al. (2015), who asserts that the magnitude of this effect depends on the development level of political and economic institutions present in a country.

Per capita income growth appears to have a negative and significant effect on infant mortality and under-five mortality rates. Erdoğan et al. (2013) and Ensor et al. (2010) also posit that per capita income growth has a negative impact on infant mortality, Houweling et al. (2005) reported that income growth reduces under-five mortality rate. Ensor et al. (2010) are of the view that due to shocks or any other reason, if the GDP per capita growth tends to fall in a country, the infant mortality rate increases, especially in the poor segment of the society as their incomes are already low and so even short run shock increases infant mortality. Similarly, O'Hare et al. (2013) report that per capita income growth decreases under-five mortality as well as infant mortality, because increased income, increases people's purchasing power and so enables them to spend on the health of their children.

Moving to the results of the equations estimated with three different dimensions of globalization, using infant mortality rate as an indicator for child health are reported in Table 2. Column 1 and 2 of Table 2 depict the results of economic globalization results for Asia and Latin America. Economic globalization (EG) tends to decrease infant mortality rate, in both the regions. However, in Latin America, economic globalization seems to have an insignificant effect on infant mortality. Such a negative relationship between economic globalization and infant mortality rate has also been reported by Welander et al. (2015). This is in contrast to the previously reported positive relationship. It also signifies that increase in economic connectivity allows for exchange of life saving technology and medicines 
in developing countries, this in turn results in better health outcomes for child. In Asia, this relationship is more robust as compared to Latin America; this higher effectiveness may be the sorry state of affairs in the region from the very beginning. The joint effect of economic globalization and democracy, viz. the interaction term $\left(\mathrm{EG}_{\mathrm{it}-1} * \mathrm{Dem}_{\mathrm{it}-1}\right)$, is negative and significant for both the regions, Asia and Latin America. This result portrays that when expansion of economic globalization and democracy takes place, side by side, they together tend to decline infant mortality and thus improve child health, in both the regions. Size of this coefficient is larger for Asia again signifying that democracy is more effective in enhancing the child health status in Asia as compared to Latin America.

Column 3 and 4 of Table 2 show the political globalization results for Asia and Latin America. Political globalization coefficient is positive for Asia and negative for Latin America, and significant at $1 \%$ for both regions. In Asia, the adverse effect of political globalization is in-line with Goryakin et al. (2015), who blame political globalization for the spread of health problems of one region to the rest of the world, through close integration and political alliance. On the other hand, in case of Latin America the results tend to reflect the finding of Welander et al. (2015). The negative effect of political globalization may be due to positive reinforcement and mutual inter-country cooperation, especially within the region. The traditional Bolivarian philosophy in South America tends to shade intergovernmental connectivity in such a way that the neighboring nations pressurize each other towards more welfare oriented egalitarian regime. This may be reflected in better life chances for the young. The interaction terms for Asia and Latin America are both negatively related with infant mortality and this relation is significant at $1 \%$ level of significance. The size of interaction term is again higher for Asia than Latin America. Welander et al. (2015) find that infant mortality tends to fall when political globalization takes place in a democratic system.

Column 5 and 6 of Table 2 show the results for social globalization for Asia and Latin America. Social globalization is positively and significantly related with infant mortality. According to Goryakin et al. (2015), social globalization can spread unhealthy food information and promote unhealthy foreign diets, which tend to negatively impact health. In the context of infant mortality it is more about misinformation regarding hygiene practices and conspiracy theories about vaccination and modern medicine that may be contributing to this outcome. Further, in developing countries there is a tendency of resisting new technology especially in the field of medicine and that resistance may be translating into negative outcomes for the most vulnerable members of society. The interaction term for both Asia and Latin America has a negative relationship with infant mortality. This 
effect is significant at $1 \%$ level of significance, for both regions. Furthermore, the coefficient size of the two interaction terms for the chosen regions is also equal to each other, i.e., 0.005 units. These results show that democracy helps to control and regulate the negative or harmful effects of social globalization, in fact standalone coefficient of democracy along with that of the interaction can allow for complete neutralization of the negative effect of social globalization.

Like the interaction terms, in all the six cases, democracy (Dem) has a negative relation with infant mortality too, in the two regions chosen. That is, an improvement in the level of democracy in Asian as well as Latin American countries, causes their child health indicators to improve. This outcome is in-line with Besley and Kudmatsu (2006)'s results, who contend that under a democratic system of government, citizens' voice is heard by the authorities and since their preferences are mostly based in the health sector, child health thus improves. Kudamatsu (2012) also reports that democratization helps to reduce infant mortality rate, through its multiparty election system and the regular change of leadership, which signifies accountability for negative outcome in areas of public interest including healthcare. The fear of this accountability means that under a democracy more resources would be allocated to healthcare especially infant and child health resulting in reduction in infant and child mortality.

Apart from the focused variables, Table 2 also reports results for the other control variables. It shows Adolescent Fertility Rate (AFR) to have a positive and significant relation with infant mortality in Asia. The Asian positive relation between infant mortality and adolescent fertility rate result is supported by Haldre et al. (2006), who posits those younger pregnancies produce infants with low surviving probability. This phenomenon in Asia is also accompanied by poor provisions for prenatal and post-natal care, lack of education and guidance available to the young mother. The institution of child marriage in itself deprives a very young girl from her childhood and the entitlement on bodily health, which factors into this pathological affect. On the other, Latin America tends to embed a negative relationship between adolescent fertility rate and infant mortality rate. The reason for this variation in signs may be the higher rate of abortions in Latin America in adolescent mothers, compared to the rate in Asia (Guttmatcher Institute, 2015). Further, better provision of healthcare and guidance to the young mother and support by elder family members also enable young mothers in ensuring child survival. In Asia most adolescent girls deliver unhealthy infants thus increasing infant mortality, while in Latin America, high level of abortions carried out by professional healthcare providers ensure that high risk pregnancies are terminated beforehand. Furthermore, owing especially to Latin America's efforts to achieve 
Millennium Development Goals and to improve maternal health, 85 percent of women visit a hospital or clinic during pregnancy, this has helped reduce infant mortality (UNICEF, 2008 and 2015). Similarly, health expenditure too is positively related with infant mortality in Asia, while negatively in Latin America. An increase in health expenditure causing infant mortality to increase, in Asia, this seems to be an odd result which may warrant a more in-depth look into the composition of healthcare expenditures and the quality of healthcare provision. Inflation (INF) appears to have a positive relation with infant mortality rate, in both the regions, however, it remains insignificant for the most part.

Results show that in Latin American infant mortality rate is positively affected by per capita income growth. O'Hare et al. (2013) reports a positive impact of per capita income growth on infant mortality, owing to distributional issues. Authors further emphasize that after a certain level of development in income has been reached, countries' child mortality appears to be disassociated with per capita income growth, this is because a larger increase is required in income, for it to instill a fall in child mortality. Pritchett and Summers (1996) report that inefficient economic performance leads to an increased infant mortality rate. O'Hare et al. (2013).

Another outstanding finding is the positive impact of female labor force participation on infant mortality in Latin America. This may be due to the nature of jobs that many mothers have to do in Latin America. The problem with a gross measure of labor force participation is that it does not include the type and nature of employment, nor does it account for wage differentials and workplace environment. Anyone of these factors can provide a better explanation for the positive effect of female labor force participation on infant mortality. In case of Asia female labor force participation tends to be low. This may explain its lack of effectiveness in affecting child health outcomes. According to Table 2 tax revenues (TR) has a negative impact on infant mortality in both Asia and Latin America. According to Reeves et al. (2015), an increase in tax revenues improves child health by increasing the number of skilled births and improving financial status of households. Levine and Rothman (2006) also report that tax revenues tend to improve children's health in a country, as they enable governments to invest in children. 
Table 2: Globalization, Democracy and Infant Mortality: Asia vs Latin America

\begin{tabular}{|c|c|c|c|c|c|c|}
\hline Column & $\begin{array}{c}\text { (1) } \\
\text { (Asia) }\end{array}$ & $\begin{array}{c}\text { (2) } \\
\text { (Latin } \\
\text { America) }\end{array}$ & $\begin{array}{c}\text { (3) } \\
\text { (Asia) }\end{array}$ & $\begin{array}{c}\text { (4) } \\
\text { (Latin } \\
\text { America) }\end{array}$ & $\begin{array}{c}\text { (5) } \\
\text { (Asia) }\end{array}$ & $\begin{array}{c}\text { (6) } \\
\text { (Latin } \\
\text { America) }\end{array}$ \\
\hline Variable & Coefficient & Coefficient & Coefficient & Coefficient & Coefficient & Coefficient \\
\hline $\mathbf{E G}_{\text {it-1 }}$ & $\begin{array}{c}-0.363^{* * * *} \\
(0.000)\end{array}$ & $\begin{array}{c}-0.0003 \\
(0.995)\end{array}$ & & & & \\
\hline $\mathbf{P G}_{\text {it-1 }}$ & & & $\begin{array}{c}0.159 * * * \\
(0.000)\end{array}$ & $\begin{array}{c}-0.105^{* * *} \\
(0.000)\end{array}$ & & \\
\hline $\mathbf{S G}_{\mathrm{it}-1}$ & & & & & $\begin{array}{c}0.221^{* * *} * \\
(0.000)\end{array}$ & $\begin{array}{c}0.079 * * \\
(0.022)\end{array}$ \\
\hline Dem $_{\text {it-1 }}$ & $\begin{array}{l}-0.116 \\
(0.321)\end{array}$ & $\begin{array}{c}-0.185^{* * * *} \\
(0.001)\end{array}$ & $\begin{array}{c}-0.444 * * * \\
(0.000)\end{array}$ & $\begin{array}{c}-0.214 * * * \\
(0.000)\end{array}$ & $\begin{array}{c}-0.515 * * * \\
(0.000)\end{array}$ & $\begin{array}{c}-0.183 * * * \\
(0.001)\end{array}$ \\
\hline $\mathbf{E G}_{\mathrm{it}-1} * \mathbf{D e m}_{\mathrm{it}-1}$ & $\begin{array}{c}-0.008 * * * \\
(0.004)\end{array}$ & $\begin{array}{c}-0.004 * * * \\
(0.000)\end{array}$ & & & & \\
\hline $\mathbf{P G}_{\mathrm{it}-1} * \mathrm{Dem}_{\mathrm{it}-1}$ & & & $\begin{array}{c}-0.004 * * * \\
(0.000)\end{array}$ & $\begin{array}{c}-0.004 * * * \\
(0.000)\end{array}$ & & \\
\hline $\mathbf{S G}_{\mathrm{it}-1} * \mathrm{Dem}_{\mathrm{it}-1}$ & & & & & $\begin{array}{c}-0.005^{* * * *} \\
(0.001)\end{array}$ & $\begin{array}{c}-0.005^{* * *} \\
(0.000)\end{array}$ \\
\hline $\mathbf{A F R}_{\text {it }}$ & $\begin{array}{c}0.165 * * * \\
(0.000)\end{array}$ & $\begin{array}{c}-0.211^{* * *} * \\
(0.000)\end{array}$ & $\begin{array}{c}0.185^{* * * *} \\
(0.000)\end{array}$ & $\begin{array}{c}-0.195 * * * \\
(0.000)\end{array}$ & $\begin{array}{c}0.188^{* * * *} \\
(0.000)\end{array}$ & $\begin{array}{c}-0.203 * * * \\
(0.000)\end{array}$ \\
\hline $\mathbf{H E}_{\mathrm{it}}$ & $\begin{array}{c}2.637 * * * \\
(0.000)\end{array}$ & $\begin{array}{c}-0.634 * * * \\
(0.001)\end{array}$ & $\begin{array}{c}2.000 * * * \\
(0.000)\end{array}$ & $\begin{array}{c}-0.656 * * * \\
(0.000)\end{array}$ & $\begin{array}{c}2.194 * * * \\
(0.000)\end{array}$ & $\begin{array}{c}-0.762 * * * \\
(0.000)\end{array}$ \\
\hline $\mathbf{I N F}_{\text {it }}$ & $\begin{array}{c}0.002 \\
(0.611)\end{array}$ & $\begin{array}{l}0.0001 \\
(0.446)\end{array}$ & $\begin{array}{c}0.016^{* * * *} \\
(0.000)\end{array}$ & $\begin{array}{c}0.00001 \\
(0.948)\end{array}$ & $\begin{array}{c}0.013^{* * * *} \\
(0.001)\end{array}$ & $\begin{array}{c}-0.0001 \\
(0.474)\end{array}$ \\
\hline PCIG $_{\text {it }}$ & $\begin{array}{l}-0.028 \\
(0.578)\end{array}$ & $\begin{array}{c}0.102 * * \\
(0.028)\end{array}$ & $\begin{array}{c}-0.00009 \\
(0.998)\end{array}$ & $\begin{array}{c}0.069 \\
(0.134)\end{array}$ & $\begin{array}{l}0.0003 \\
(0.992)\end{array}$ & $\begin{array}{c}0.120 * * * \\
(0.006)\end{array}$ \\
\hline $\mathbf{L F P F}_{\text {it }}$ & $\begin{array}{c}0.030 \\
(0.676)\end{array}$ & $\begin{array}{c}0.382 * * * \\
(0.000)\end{array}$ & $\begin{array}{l}-0.018 \\
(0.817)\end{array}$ & $\begin{array}{c}0.326 * * * \\
(0.000)\end{array}$ & $\begin{array}{l}-0.036 \\
(0.661)\end{array}$ & $\begin{array}{c}0.332 * * * \\
(0.000)\end{array}$ \\
\hline $\mathbf{T R}_{\mathrm{it}}$ & $\begin{array}{c}-0.430 \text { *** } \\
(0.000)\end{array}$ & $\begin{array}{c}-0.048^{* * * *} \\
(0.003)\end{array}$ & $\begin{array}{c}-0.509^{* * * *} \\
(0.000)\end{array}$ & $\begin{array}{c}-0.045^{* * *} \\
(0.002)\end{array}$ & $\begin{array}{c}-0.565 * * * \\
(0.000)\end{array}$ & $\begin{array}{c}-0.052 * * * \\
(0.002)\end{array}$ \\
\hline $\mathbf{A} \mathbf{H}_{\mathrm{it}}$ & $\begin{array}{c}-4.094 * * * \\
(0.000)\end{array}$ & $\begin{array}{c}-4.264 * * * \\
(0.000)\end{array}$ & $\begin{array}{c}-3.692 * * * \\
(0.000)\end{array}$ & $\begin{array}{c}-3.984 * * * \\
(0.000)\end{array}$ & $\begin{array}{c}-3.815^{* * * *} \\
(0.000)\end{array}$ & $\begin{array}{c}-4.287 * * * \\
(0.000)\end{array}$ \\
\hline $\mathbf{H K}_{\text {it }}$ & $\begin{array}{c}15.869 * * * \\
(0.000)\end{array}$ & $\begin{array}{c}-14.488^{* * *} * \\
(0.000)\end{array}$ & $\begin{array}{c}12.253^{* * *} * \\
(0.000)\end{array}$ & $\begin{array}{c}-11.194 * * * \\
(0.000)\end{array}$ & $\begin{array}{c}13.694 * * * \\
(0.000)\end{array}$ & $\begin{array}{c}-14.951 * * * \\
(0.000)\end{array}$ \\
\hline $\begin{array}{l}\text { No. of } \\
\text { observations/ } \\
\text { No. of } \\
\text { countries }\end{array}$ & $917 / 25$ & $716 / 18$ & $900 / 26$ & $726 / 19$ & $900 / 26$ & $773 / 19$ \\
\hline $\begin{array}{l}\text { Hansen test (p } \\
\text { value) }\end{array}$ & 0.538 & 0.179 & 0.408 & 0.122 & 0.247 & 0.187 \\
\hline
\end{tabular}

The endogenous variable, adult health, measured through life expectancy, has also a negative and significant effect on infant mortality. Currie (2008) proposes that this inverse relation is present because of the reason that healthier adults produce healthier infants and sick parents tend to report sick children. Therefore, high life expectancy or healthier adults help to decline the infant mortality rates. Atrash (2015) indicates that if parents' survival rate increases, especially mother's, the child mortality rate tends to decrease. Also, that health and survival of the 
parents is important for children especially under the age of five, as they need their parents to take care of them economically as well as nutritionally.

The effect of human capital is significant at $1 \%$ level of significance in both, Asia and Latin America. In Asia, the two seem to be positively related. This positive link shows that affirmative human capital outcome is not instrumental in reducing infant mortality in Asia. Again, we have to see the nature of the indicator to explain this phenomenon. The human capital index captures educational achievement not quality or educational distribution. Therefore, the pockets of population with lower education have higher fertility rates and higher infant mortality. The significance of the positive effect may also be indicative of the size of these strata and complacency of the government attributed to the encouraging human capital figures. In Latin America, one unit increase in human capital reduces the infant mortality rate by around 11 to 15 units. Hasnaa and Ibrahim (2014) also posit that there exists an inverse relationship between human capital and infant mortality, because human capital increases income, which improves health services approachability and thus improves child health.

In order to examine the effect of dimensions of globalization with the same mediators as above, but on under-five mortality, instead of infant mortality, the six equations were estimated again. These equations reaped the results, reported in Table 3. All three dimensions of globalization are negative and highly significant for Asia, providing a compelling case for deeper global connectivity for the region. However, in case of Latin America globalization tends to adversely affect life chances of children under five. This signifies that the negative ramifications of globalization discussed previously dominate its advantages in case of Latin America. The interaction terms are also significant and negative for both the regions, signifying desirability of more democratic regimes for Asia as well as Latin America. The direct effect of democracy in case of Asia is negative and significant, further strengthening the implications of the results of the interaction term. For Latin America, however, the impact of democracy on under-five mortality is insignificant, signifying that democracy is only indirectly effective in reducing under-five mortality in the region. The impact of democracy is translated through globalization in case of Lain America. 
Table 3: Globalization, Democracy and Under-five Mortality: Asia vs Latin America

\begin{tabular}{|c|c|c|c|c|c|c|}
\hline Column & $\begin{array}{c}(1) \\
\text { (Asia) }\end{array}$ & $\begin{array}{c}\text { (2) } \\
\text { (Latin } \\
\text { America) } \\
\end{array}$ & $\begin{array}{c}\text { (3) } \\
\text { (Asia) }\end{array}$ & $\begin{array}{c}\text { (4) } \\
\text { (Latin } \\
\text { America) }\end{array}$ & $\begin{array}{c}\text { (5) } \\
\text { (Asia) }\end{array}$ & $\begin{array}{c}\text { (6) } \\
\text { (Latin } \\
\text { America) } \\
\end{array}$ \\
\hline Variable & Coefficient & Coefficient & Coefficient & Coefficient & Coefficient & Coefficient \\
\hline $\mathbf{E G}_{\text {it-1 }}$ & $\begin{array}{c}-0.659 * * * \\
(0.000)\end{array}$ & $\begin{array}{l}0.142 * * \\
(0.040)\end{array}$ & & & & \\
\hline $\mathbf{P G}_{\text {it-1 }}$ & & & $\begin{array}{c}-0.236^{* * *} * \\
(0.000)\end{array}$ & $\begin{array}{c}-0.013 \\
(0.669)\end{array}$ & & \\
\hline$S_{\text {it-1 }}$ & & & & & $\begin{array}{c}-0.268 * * * \\
(0.000)\end{array}$ & $\begin{array}{c}0.324 * * * \\
(0.000)\end{array}$ \\
\hline Dem $_{\text {it-1 }}$ & $\begin{array}{c}-0.694 * * * \\
(0.000)\end{array}$ & $\begin{array}{c}0.039 \\
(0.563)\end{array}$ & $\begin{array}{c}-0.784 * * * \\
(0.000)\end{array}$ & $\begin{array}{c}0.044 \\
(0.521)\end{array}$ & $\begin{array}{c}-0.882 * * * \\
(0.000)\end{array}$ & $\begin{array}{l}-0.003 \\
(0.958)\end{array}$ \\
\hline $\mathbf{E G}_{\mathrm{it}-1} * \mathrm{Dem}_{\mathrm{it}-1}$ & $\begin{array}{c}-0.009 * * * \\
(0.000)\end{array}$ & $\begin{array}{c}-0.007 * * * * \\
(0.000)\end{array}$ & & & & \\
\hline PG $_{\text {it-1 }} * D_{\text {Dem }}$ it-1 & & & $\begin{array}{c}-0.008 * * * \\
(0.000)\end{array}$ & $\begin{array}{c}-0.005 * * * \\
(0.000)\end{array}$ & & \\
\hline$S_{\text {it-1 }} * D m_{i t-1}$ & & & & & $\begin{array}{c}-0.010 * * * \\
(0.000)\end{array}$ & $\begin{array}{c}-0.009 * * * \\
(0.000)\end{array}$ \\
\hline $\begin{array}{l}\text { No. of } \\
\text { observations/ No. } \\
\text { of countries }\end{array}$ & $816 / 23$ & $686 / 18$ & $900 / 26$ & $726 / 19$ & $900 / 26$ & $726 / 19$ \\
\hline $\begin{array}{l}\text { Hansen test (p } \\
\text { value) }\end{array}$ & 0.263 & 0.392 & 0.292 & 0.482 & 0.113 & 0.257 \\
\hline
\end{tabular}

Note: P-values of each coefficient are reported in (). ***,** and * show 1\%, 5\% and $10 \%$ level of significance, respectively. Results for p-value for Hansen test are also mentioned. Results are estimated using GMM technique.

The results on the whole represent the shortcomings of a one size fit all solution to the issue of child health given the differing outcome for the two regions. The few things which are consistent for all regions is that democracy is desirable owing to its direct as well as indirect effect through globalization. Globalization while showing inconsistent signs based on its dimensions becomes desirable in the presence of a more democratic regime. Most of our expectations are confirmed by these results and we can now present a compelling case for globalizationdemocracy combination as a viable recourse for achievement in positive child health outcomes.

\section{Conclusions}

The results of the study depict that globalization and its dimensions (economic, social and political) tend to have mixed effects on child health. Economic globalization tend to significantly improve child health in Asia, however, it has detrimental effect in Latin America. Political globalization increases infant mortality in Asia but reduces child mortality in the region. In Latin America it is found to cause better outcomes in terms of child health. Social mobilization increases infant and child mortality in Latin America while in Asia it reduces child mortality and enhances infant mortality. 
All in all, social globalization was found to be most detrimental to child health, which might be attributed to spreading of conspiracy theories and misinformation regarding vaccination, hygiene and potential health issues. The impact of economic globalization is inconsistent perhaps because of structural differences between the two regions. In Latin America close economic links between the countries in the region means that both products and labors move more freely than in Asia. That combined with highly pronounced health discrepancies between the countries in the region allows for more rapid transference of infections and diseases undermining the affirmative effects of economic globalization in terms of access to better health technologies. Democracy generally tends to improve child health in Asia but in Latin America it is only significant in case of infant mortality. The interaction of level of democracy and globalization was found to be consistently effective in reducing infant and child mortality.

These results depict complementarity between globalization and democracy in reducing infant mortality and child mortality. This complementarity despite diverging effects of the two phenomena individually, shows that globalization can be less detrimental or more conducive to child health in the presence of high levels of democracy. This makes a strong case of strengthening democratic systems in both Latin America and Asia. The results also point towards very different natures of trade and inter-regional connectivity in the two regions and its effects in terms of child health. This adds a new dimension to the challenges the regions face in this highly connected and globalized world and offers democratic reforms as one way to counter the detrimental effects of globalization. 


\section{References}

Azevedo, M. J., \& Johnson, B. H. (2011). The impact of globalization determinants and the health of the world's population. New knowledge in a new era of globalization. 165-182, InTech: London.

Bergh, A., \& Nilsson, T. (2010). Good for living? On the relationship between globalization and life expectancy. World Development, 38(9), 1191-1203.

Besley, T., \& Kudamatsu, M. (2006). Health and democracy. American Economic Review, 96(2), 313-318.

Bhalotra, S. R., \& Pogge, T. (2012). Ethical and economic perspectives on global health interventions. Policy Papers Series, Study of Labor, IZA, 38.

Burroway, R. (2016). Democracy and child health in developing countries. International Journal of Comparative Sociology, 57(5), 338-364.

Cornia, G. A. (2001). Globalization and health: Results and options. Bulletin of the World Health Organization, 79, 834-841.

Currie, J. (2008). Child Health and Mortality. Palgrave Macmillan: London. Available at: https://doi.org/10.1057/978-1-349-95121-5_2828-1

Currie, J. (2009). Healthy, wealthy, and wise: Socioeconomic status, poor health in childhood, and human capital development. Journal of Economic Literature, 47 (1), 87-122.

Deaton, A. (2004). Health in an age of globalization. National Bureau of Economic Research, Working Paper, 10669.

Diaz-Bonilla, E., Babinard, J., Pinstrup-Anderson, P. \& M. Thomas (2002). Globalizing health benefits for developing countries. Trade and Macroeconomics Division, International Food Policy Research Institute, Discussion Paper, 108.

Dithmer, J., \& Abdulai, A. (2020). Trade openness and child health: A heterogeneous panel cointegration analysis. Applied Economics, 52(23), 2508-2525.

Dreher, A. (2006). Does globalization affect growth? Evidence from a new index of globalization. Applied Economics, 38(10), 1091-1110.

Dreher, A., Gaston, N., \& Martens, P. (2008). Measuring globalization: Gauging its consequences, Springer Science \& Business Media. 
Ensor, T., Cooper, S., Davidson, L., Fitzmaurice, A., \& Graham, W. J. (2010). The impact of economic recession on maternal and infant mortality: Lessons from History. BMC Public Health, 10(1), 2-9.

Erdoğan, E., Ener, M., \& Arıca, F. (2013). The strategic role of infant mortality in the process of economic growth: An application for high income OECD countries. Procedia-Social and Behavioral Sciences, 99, 19-25.

Fukuyama, F., \& Marwah, S. (2000). Dimensions of development. Journal of Democracy, 11(4), 80-94.

Goryakin, Y., Lobstein, T., James, W. P. T., \& Suhrcke, M. (2015). The impact of economic, political and social globalization on overweight and obesity in the 56 low and middle income countries. Social Science and Medicine, 133, $67-76$.

Hayakawa, K. (2007). Small sample bias properties of the system GMM estimators in dynamic panel data models. Economics Letters, 95(1), 32-38.

Houweling, T. A., Kunst, A. E., Looman, C. W., \& Mackenbach, J. P. (2005). Determinants of under 5 mortality among the poor and the rich: A crossnational analysis of 43 developing countries. International Journal of Epidemiology, 34(6), 1257-1265.

Keefer, P. (2007). Clientelism, credibility, and the Policy choices of young democracies. American Journal of Political Science, 51(4), 804-821.

Kickbusch, I. (2004). The end of public health as we know it: constructing global health in the 21st Century. Hugh R. Leavell lecture series, World Federation of Public Health Association (WFPHA), $10^{\text {th }}$ International Congress on Public Health. Available at: http://sdnhq.undp.org/gpgn/r-health.php.

Levine, D. I., \& Rothman, D. (2006). Does trade affect child health? Journal of Health Economics, 25, 538-554.

Martens, P., Akin, S., Maud, H., \& Mohsin, R. (2010). Is globalization healthy: A statistical indicator analysis of the impacts of globalization on health. Globalization and Health, 6, 1-16.

Mesagan, P. E., \& Adeniji-Ilori, O. M. (2018). Household environmental factors and childhood morbidity in South-Western Nigeria. Fudan Journal of the Humanities and Social Sciences,11(3), 411-425. Available at: https://doi.org/10.1057/9780230304673_5 
Mills, A. (2011). Health systems in low and middle-income countries. The Oxford Handbook of Health Economics, 30-57, Oxford University Press: Oxford.

Nayyar, D. (2015). Globalization and democracy. Revista de Economia Política, 35(3), 388-402.

O'Hare, B., Makuta, I., Chiwaula, L., \& Bar-Zeev, N. (2013). Income and child mortality in developing countries: A systematic review and metaanalysis. Journal of the Royal Society of Medicine, 106(10), 408-414.

Olayiwola, K., Soyibo, A., \& Atinmo, T. (2004). Impact of globalization on food consumption, health and nutrition in Nigeria. Economic Policy Unit, Development Policy Centre, Ibadan, Nigeria.

Östlin, P. (2004). Priorities for research to take forward the health equity policy agenda. Report from the WHO Task Force on Health System Research Priorities for Equity in Health. Available at: www.who.int/rpc/meetings/en/Task_Force\%20Report_Nov_Final[2].pdf.

Papageorgiou, C., Savvides, A., \& Zachariadis, M. (2007). International medical technology diffusion. Journal of International Economics, 72(2), 409-427.

Powell-Jackson, T., Basu, S., Balabanova, D., McKee, M., \& Stuckler, D. (2011). Democracy and growth in divided societies: A health inequality trap? Social Science and Medicine, 73(1), 33-41.

Rodrik, D. (1998). Why do more open economies have bigger governments? Journal of Political Economy, 106(5), 997-1032.

Rosenfield, A., \& Schwartz, K. (2005). Improving the health of women in developing countries: The time is now. Journal of Midwifery and Women's Health, 50(4), 272-274.

Rudra, N. (2002). Globalization and the decline of the welfare state in lessdeveloped countries. International Organization, 56(2), 411-445.

Rudra, N., \& Haggard, S. (2005). Globalization, democracy, and effective welfare spending in the developing world. Comparative Political Studies, 38(9), 1015-1049.

Seyfried, L., \& Bednarzik, R. (2011). Family planning and maternal health: The effects of family planning on maternal health in the Democratic Republic of Congo (unpublished doctoral dissertation). Graduate School of Arts and Sciences, Georgetown University. 
Shandra, J. M., Nobles, J. E., London, B., \& Williamson, J. B. (2005). Multinational corporations, democracy and child mortality: A quantitative, cross national analysis of developing countries. Social Indicators Research, 73(2), 267293.

Sinn, H. W. (1997). The selection principle and market failure in system competition. Journal of Public Economics, 66(2), 247-274.

Spalding, N. L. (1990). The relevance of basic needs for political and economic development. Studies in Comparative International Development, 25(3), 90-115.

Tanahashi, K. (2007). Health Impact of Globalization. Available at: http://repository.tku.ac.jp/dspace/handle/11150/862

Torrance, G. W., Thomas, W. H., \& Sackett, D. L. (1972). A utility maximization model for evaluation of health care programs. Health Services Research, 7(2), 118-133.

Wagner, Z., Heft-Neal, S., Bhutta, Z. A., Black, R. E., Burke, M., \& Bendavid, E. (2018). Armed conflict and child mortality in Africa: A geospatial analysis. The Lancet, 392(10150), 857-865.

Wamala, S. (2009). The Impact of globalization on maternal and child health. Maternal and Child Health, 135-149, Springer: US.

Wang, L. (2003). Determinants of child mortality in LDCs: Empirical findings from demographic and health surveys. Health policy, 65(3), 277-299.

Welander, A., Lyttkens, C. H., \& Nilsson, T. (2015). Globalization, democracy and child health in developing countries. Social Science and Medicine, 136, 5263.

Woodward, D., Drager, N., Beaglehole, R., \& Lipson, D. (2001). Globalization and health: A framework for analysis and action. Bulletin of the World Health Organization, 79, 875-881.

Zakaria, M., Tariq, S., \& Ul Husnain, M. I. (2020). Socio-economic, macroeconomic, demographic, and environmental variables as determinants of child mortality in South Asia. Environmental Science and Pollution Research, 27(1), 954-964.

Zgurovsky, A. M. (2007). Risks and gains of globalization for developing countries, Russian Journal of Earth Sciences, 9(2), 1-7. 


\section{Appendix}

FigureA-1: Infant Mortality Rate in Asia and Latin America

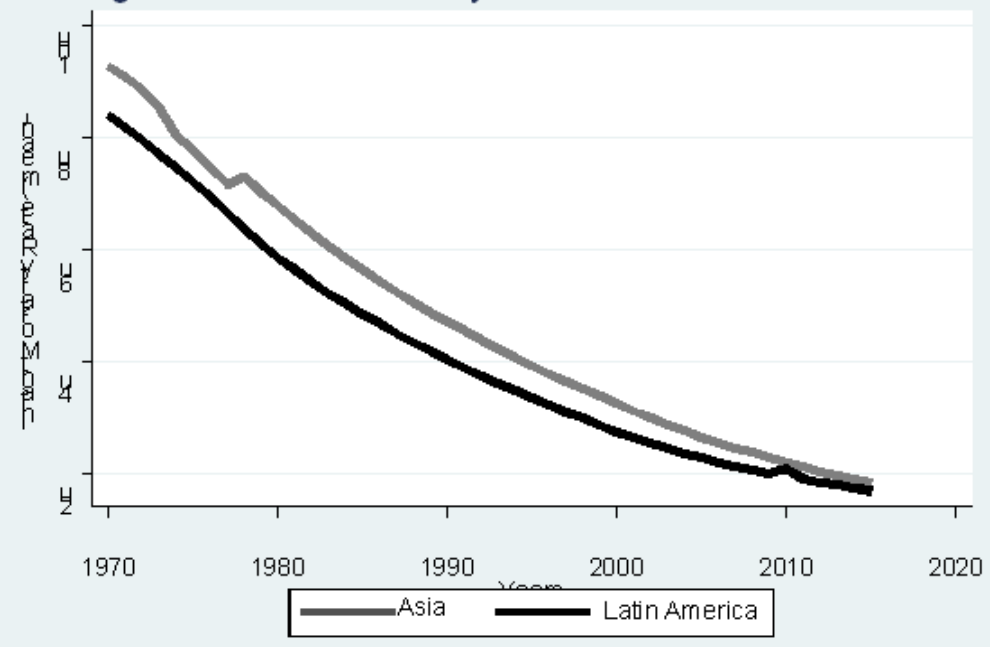

